\title{
Pandangan Alkitab Perjanjian Baru Terhadap Praktik Minyak Urapan Pada Gereja Masa Kini
}

\author{
Marthen Mau \\ Sekolah Tinggi Teologi Arastamar Ngabang \\ marthenmau@gmail.com
}

\begin{abstract}
This research examines the New Testament Bible's view of the practice of anointing oil in the church today. In essence, consuming excess oil or oily foods will cause a high cholesterol risk. However, the exposure of the New Testament Bible's view of the practice of anointing oil in the church today under study, especially that oil does not contain cholesterol, but brings about medicine that heals the body, soul, and spirit.
\end{abstract}

Keywords: New Testament Bible, oil, and the church today

Abstrak: Riset ini mengupas tentang pandangan Alkitab Perjanjian Baru terhadap praktik minyak urapan pada gereja masa kini. Pada hakikatnya kelebihan mengonsumsi minyak atau makanan yang berminyak akan menimbulkan berisiko kolesterol tinggi. Namun, pemamaran pandangan Alkitab Perjanjian Baru terhadap praktik minyak urapan pada gereja masa kini yang diteliti, khususnya minyak tidak mengandung kolesterol, melainkan mendatangkan obat yang menyembuhkan tubuh, jiwa, dan roh.

Kata Kunci: Alkitab Perjanjian Baru, minyak, dan gereja masa kini

\section{Pendahuluan}

Bahwasanya minyak identik dengan kegemukan. Sebab itu minyak menjadi musuh utama atau terbesar bagi mereka yang memiliki animo yang besar untuk menurunkan berat badan. Tetapi, tidak demikian halnya dengan minyak zaitun. Dalam sebuah penelitian yang dimuat dalam The British Journal of Nutrition disebutkan penggunaan minyak zaitun sebagai pengganti minyak jenuh untuk kebutuhan seharihari selama empat minggu, tanpa mengubah pola makan dapat mengurangi berat badan 2-3 kilogram. Minyak zaitun mengandung beberapa senyawa, seperti fenol, tokoferol, sterol, pigmen, dan squalene yang memegang peranan penting dalam kesehatan manusia. Minyak zaitun juga mengandung trigliserol yang sebagian besar berupa asam lemak tidak jenuh tunggal jenis asam oleat, yang saat ini dikenal dengan sebutan omega-9. Minyak ini pun kaya akan vitamin A, B1, B2, C, D, E, K, zat besi, dan bebas kolesterol.

Berbagai riset membuktikan, sebagaimana diulas di dalam salah satu Journal yang berjudul Fakta dan Manfaat Minyak Zaitun Book (2015) bahwa minyak zaitun memiliki seribu satu khasiat. Minyak nabati yang berasal dari Timur Tengah ini dapat berperan sebagai antimikroba, antikanker, antihipertensi, antidiabetes, antiaging dan bahkan sangat baik untuk kecantikan dan bisa digunakan dengan berbagai cara. Minyak zaitun dapat digunakan pada tangan, rambut dan sebagai bahan untuk massage oil atau pijat urut, membuat rambut mengkilap dan menghilangkan ketombe, menghambat penuaan serta menghilangkan kerutan kulit, dapat juga menurunkan tekanan darah tinggi, mengurangi sakit perut dan mulas, mengurangi jerawat serta bekas jerawat pada kulit, dipijat pada seluruh tubuh dapat menghilangkan rasa letih, sakit, pegal pada otototot tubuh dan menurunkan oksidasi kolesterol Low Density Lipoprotein (LDL).

Corey menyatakan bahwa minyak zaitun merupakan minyak yang berasal dari perasan buah zaitun, sedangkan minyak zaitun extra virgin adalah hasil olahan pertama, tanpa campuran ekstrak lainnya. Minyak zaitun telah digunakan sejak 400SM oleh 
Hipocrates untuk membuat resep terapi penyembuhan pasien dan sejak 6000 tahun yang lalu, minyak zaitun banyak digunakan untuk kesehatan jiwa dan kesehatan badan. ${ }^{1}$

Minyak zaitun telah banyak digunakan untuk diet di berbagai daerah, khususnya daerah Mediterania dengan dikonsumsi secara langsung, maupun dicampur dengan salad. Trubus berkomentar bahwa negeri Yunani merupakan pengguna minyak zaitun terbanyak, dengan rata-rata konsumsi sebanyak 27,3 kg per kapita per tahun. Posisi ke dua dan ketiga adalah Spanyol dan Italia, masing-masing sebesar 13,62 kg dan 12,35 kg per kapita per tahun. ${ }^{2}$ Menurut Canela, et al (210:245) bahwa negara-negara di Eropa Selatan, seperti Prancis, Spanyol, Yunani, Italia dan Portugal, banyak menggunakan minyak zaitun ini sebagai diet, dan didapatkan bahwa negara-negara tersebut lebih rendah tingkat mortalitasnya akibat penyakit jantung dibandingkan dengan negaranegara lain di Eropa Utara. Penjelasan dari Pons, et al (2007:84) bahwa Minyak zaitun banyak diminati di daerah-daerah Mediterania karena tingginya kandungan Monounsaturated Fatty Acids (MUFA) dan antioksidan alamiah yang baik untuk kesehatan sebagai langkah pencegahan resiko penyakit kardiovaskuler.

Kalahi (2014)) mengutarakan bahwa di Asia penggunaan minyak zaitun untuk kecantikan dan kesehatan banyak ditemukan di negara-negara timur tengah, seperti Mesir dan Arab. Penggunaannya di Indonesia banyak ditemui untuk keperluan kecantikan. Penggunaan minyak zaitun yang masih sedikit di Asia khususnya Indonesia, jika dibandingkan dengan negara-negara Eropa menjadi pertanyaan tersendiri, padahal saat ini minyak zaitun mudah sekali didapatkan ditoko-toko Arab, dan di beberapa Apotik dengan berbagai macam kemasan, mulai dari 250 ml- 2 lt. Harga minyak zaitun extra virgin masih terjangkau, penggunaannya juga yang hanya sedikit (+15 ml) setiap harinya, sehingga dapat disimpan untuk beberapa hari, bahkan beberapa bulan ke depan.

Trubus menyatakan bahwa manfaat minyak zaitun diantaranya adalah dapat menurunkan berat badan, menurunkan kadar kolesterol, pencegahan kanker dan jantung koroner. ${ }^{3}$ Supriadi mengisahkan bahwa minyak zaitun extra virgin mengandung tinggi polifenol yaitu sebanyak 400,274 ppm. ${ }^{4}$ Polifenol adalah senyawa kimia alami sebagai antioksidan yang membantu melindungi sel-sel dari radikal bebas dan dapat mencegah resiko penyakit jantung. Athiroh menarasikan bahwa polifenol memberikan efek vasodilator dalam pembuluh darah melalui peningkatan Nitric Oxide Syntase (NOS), merangsang quanylate cyclase dan membentuk cGMP sehingga terjadi vasodilatasi pembuluh darah. ${ }^{5}$ Kandungan polifenol dalam minyak zaitun lebih tinggi 10 kali lipat dibandingkan teh hijau yang digadang-gadang sebagai antikanker, darah tinggi, diabetes, stroke, dan jantung koroner, oleh karena itu sangat cocok sebagai pilihan untuk mendapatkan kesehatan. ${ }^{6}$

Minyak zaitun extra virgin juga banyak mengandung lemak tidak jenuh tunggal yang dapat meningkatkan jumlah High Density Lipoprotein (HDL) dan menurunkan kadar kolesterol jahat atau Low Density Lipoprotein (LDL). ${ }^{7}$ LDL dalam darah menyebabkan menempelnya lemak-lemak jahat penyebab timbulnya plak yang

1 Gerald Corey, Teori dan Praktek Konseling dan Psikoterapi, penerjemah E. Koeswara (Bandung: Penerbit PT. Refika Aditama 2008), 19

2 Trubus, Herbal Indonesia Berkhasiat: Bukti Ilmiah dan Cara Racik (Bogor: Trubus Swadaya, 2010), 54

3 Ibid. 54-64

4 Deni Supriadi, Pengaruh Persepsi Siswa Tentang Metode Mengajar Guru Dan Pemanfaatan Sarana Belajar IPS Terpadu Siswa Kelas VII Semester Ganjil SMP 17 Serdang Tahun Pelajaran 2012/2013 (....: Unila, 2013), 18

5 N. A. S. Athiroh, Scurrula atropurpurea increases nitric oxide and decreases malondialdehyde in hypertensive rats (....: Universa Medicana, 2012), 1

${ }^{6}$ Trubus, op.cit., 58

7 Ibid. 60 
menyebabkan pengecilan lumen pembuluh darah sehingga aliran terhambat dan tekanan darah naik. Lemak-lemak yang dibawa oleh LDL dapat diluruhkan dengan meningkatkan HDL karena kerja HDL adalah membawa lemak-lemak yang menempel pada dinding arteri, sehingga membuat aliran darah menjadi lancar.

Kandungan polifenol dan lemak tidak jenuh yang terdapat pada minyak zaitun extra virgin, dapat membantu melancarkan peredaran darah. Hal ini dapat menjadi alternatif pengobatan hipertensi sebagai terapi komplementer pendamping pengobatan secara farmakologis. Hipertensi diartikan sebagai peningkatan tekanan darah secara terus-menerus hingga melebihi batas normal. Badan Penelitian dan Pengembangan Kesehatan Departemen Kesehatan Republik Indonesia (2007), melaporkan kejadian hipertensi di Indonesia berdasarkan hasil survei riset kesehatan dasar (Rikesdas) pada tahun 2007-2008, telah mencapai 31,7\% dari total penduduk dewasa dan mencapai 6,8\% dari proporsi penyebab kematian pada semua umur. Hal itu menobatkan hipertensi sebagai penyakit penyebab kematian nomor tiga setelah stroke dan tuberkulosis. ${ }^{8}$ Sementara itu, data dari Propinsi Jawa Timur, penderita hipertensi dari tahun 2009 sebesar 4,20\% mengalami peningkatan 4,89\% pada tahun $2010 .{ }^{9}$ Tidak menjadi hal yang mustahil jika beberapa tahun kemudian penyakit ini akan bergeser menjadi peringkat pertama penyebab kematian di Indonesia, karena diperkirakan terdapat 76\% kasus hipertensi di masyarakat yang belum terdiagnosis. ${ }^{10}$

Ridjab mengutarakan bahwa prevalensi hipertensi akan semakin meningkat jika kasus hipertensi dibiarkan tidak tertangani dengan baik. Hipertensi dengan sebutannya sebagai Silent Killer, merupakan faktor resiko utama penyakit kardiovaskular. ${ }^{11}$ Fakta yang terjadi di lingkungan masyarakat, bahwa tingginya angka kejadian hipertensi di Indonesia, tidak dibarengi dengan angka kepatuhan penderita hipertensi untuk menjalani pengobatan. Syamsudin menjelaskan bahwa hanya sekitar 0,4\% dari 31,7\% kasus yang meminum obat hipertensi untuk pengobatan. ${ }^{12}$ Rendahnya penderita hipertensi untuk berobat, dikarenakan hipertensi tidak menunjukkan gejala dan tanda khas yang bisa dipakai sebagai peringatan dini. Ketidakpatuhan penderita dalam pengobatan dapat memperburuk keadaan, karena hipertensi yang dibiarkan tidak tertangani, bisa menyebabkan pecahnya pembuluh darah serebral, penyakit arteri koroner, dan gagal ginjal. ${ }^{13}$

Pengobatan hipertensi dapat dilakukan melalui dua cara, pengobatan farmakologis dan non-farmakologis. Pengobatan farmakologis dapat dilakukan dengan cara memberikan obat-obat anti hipertensi seperti, diuretik, obat-obatan golongan $\beta$ simpstolitik seperti propanolol, metaprolol, dan sotalol, obat-obatan ACEI seperti kaptopril, enalapril dan lain-lain. Perhatian khusus harus diberikan karena obat-obat kimia selalu disertai efek samping, baik efek jangka pendek maupun jangka panjang. Menurut Ikawati, dkk, bahwa efek samping obat anti hipertensi jangka pendek biasanya berupa batuk, konstipasi, dan untuk jangka panjang, dapat menyebabkan peningkatan asam urat, pencetus asam gout, meningkatnya glukosa darah, hipokalemia, bahkan bisa menyebabkan ISPA (Infeksi Saluran Pernafasan Atas). Sedangkan pengobatan non-

${ }^{8}$ A. R. Syamsudin, Metode Penelitian Pendidikan Bahasa (Bandung: PT. Remaja Rosdakarya, 2011),

9 Dinas Kesehatan Propinsi Jawa Timur, Profil Kesehatan Provinsi Jawa Timur Tahun 2009 (Surabaya: Dinkes Propinsi Jatim, 2010), 12

10 A. R. Syamsudin, op.cit., 22

11 D. A. Ridjab, Pengaruh Aktivitas Fisik terhadap Tekanan Darah (Jakarta: Majalah Kedokteran Atma Jaya, 2011), 159

12 A. R. Syamsudin,, op.cit., 22

13 H. T. Prasetyorini HT \& D. Prawesti, Stress Pada Penyakit Terhadap Kejadian Komplikasi Hipertensi Pada Pasien Hipertensi (....: Jurnal STIKES, 2012), 62 
farmakologis yaitu pengobatan yang tidak menggunakan bahan-bahan obat kimia. ${ }^{14}$ Setyoadi \& Kushariadi (2011) menambahkan bahwa salah satu pengobatan nonfarmakologis yang dapat dilakukan adalah menjaga berat badan tetap normal, pola hidup sehat, konsumsi rendah garam, diet DASH dan terapi komplementer. Terapi komplementer dapat dilakukan sebagai pendamping pengobatan farmakologis.

Berdasarkan pernyataan-pernyataan para ahli yang saya narasikan di atas, maka dapat dipahami secara simpel bahwa minyak zaitun dengan bantuan Sang Pemberi yaitu Tuhan Kristus Yesus melalui Roh-Nya, maka ketika umat manusia mengkonsumsi minyak zaitun pasti mengalami kesembuhan atas penyakit-penyakit yang dideritakannya. Bahkan minyak zaitun mampu mencegah timbulnya berbagai penyakit yang sewaktu-waktu muncul dalam tubuh manusia. Karena itu, minyak zaitun sangat baik untuk dikonsumsi selain digunakan untuk dioles-olesan pada organ-organ tubuh yang terkena sakit. Demikian pula, minyak zaitun extra virgin dengan kandungan polifenol dan lemak tidak jenuhnya yang mampu melancarkan aliran darah, dapat digunakan sebagai terapi komplementer pendamping pengobatan farmakologis.

\section{Metode Penelitian}

Pada penelitian ini, penulis atau peneliti menggunakan pendekatan atau metode kualitatif untuk memperoleh data yang valid guna membangun sebuah teori yang berkaitan dengan tema atau pokok penelitian. Metode kualitatif yang dimaksud adalah mengkaji dan mengelaborasi setiap sumber, informasi dan data-data yang diperoleh dari pustaka.

\section{Hasil dan Pembahasan}

A. Kata yang dipergunakan PB untuk menjelaskan minyak adalah kata Yunani "Elaion" Yaitu artinya minyak Zaitun; minyak (Mat. 25:3, 4; 25:8; Mrk. 6:13; Luk. 7:46; 10:34; 16:6; Ibr. 1:9; Yak. 5:14; Why. 6:6; 18:13

\section{Matius 25:3, 4}

Kata "minyak," dalam bahasa Yunani disebut elaion. Kata 'elaion,' dalam bentuk kata benda accusative ${ }^{15}$ singular neutor dan dalam bahasa Inggris kata ini disebut sebagai olive atau oil oil. ${ }^{16}$ Karena konteks ini adalah konteks perumpamaan, maka kata elaion mengandung makna bahwa minyak zaitun memberi kekuatan, keteguhan, kesabaran, dan kemampuan dalam menantikan sesuatu/seseorang yang akan datang.

Jadi, konteks ini membicarakan tentang mempelai laki-laki, yaitu Yesus Kristus ${ }^{17}$ atau mempelai laki-laki adalah Mesias. ${ }^{18}$ Pernyataan ini dapat dijelaskan bahwa orangorang yang telah percaya kepada Yesus Kristus sebagai mempelai perempuan dan Dia sebagai mempelai laki-laki yang perlu dinantikan dengan sabar oleh orang-orang percaya. Ungkapan minyak dalam konteks ini dilambangkan sebagai iman berarti orang percaya perlu memiliki kekuatan, kesabaran, keteguhan, dan kemampuan untuk

\footnotetext{
14 Ikawati, dkk., Kajian Keamanan Pemakaian Obat Antihipertensi di Poliklinik Usia Lanjut RS DR. Sardjito (Yogyakarta: Jurnal Farmasi Indonesia, 2008), 164

15 Accusative artinya penderita. Bandingkan John M. Echols dan Hassan Shadiliy, Kamus Inggris Indonesia. Jakarta: PT Gramedia Jakarta, 2005hal. 7

16 Scripture4all Foundation - www.scripture4all.org, 2010 hal. 14

17 Pdt. Dr. Paskalinus Busthan, M. Th., Bahan Ajar Syemenologi (Pontianak: STT Pontianak, 2017),

18 Donald Guthrie, dkk (terj), Tafsiran Alkitab Masa Kini 3 Matius-Wahyu (Jakarta: YKBK/OMF, 1999), 114
} 
menantikan Kristus Yesus datang yang kedua kalinya. Pernyataan ini diselaraskan dengan ungkapan di dalam penjelasan Alkitab Penuntun Hidup Berkelimpahan:

Dengan mempergunakan serangkaian gambaran, Yesus menekankan perlunya kesetiaan dan kesiagaan sampai Ia kembali. Perumpamaan mengenai ke-10 gadis ini menekankan perlunya ketekunan dalam iman dan kesiapan rohani mengingat Dia akan datang pada hari yang tak terduga. Minyak dalam perumpamaan ini melambangkan iman yang sejati, kebenaran, dan kehadiran Roh Kudus yang terus-menerus. Lima perumpamaan lain yang menekankan ketekunan adalah perumpamaan penabur (Luk. 8:4-15); pemilik rumah (Luk. 12:35-40); pengawas (Luk. 12:42-48); pembangun menara (Luk. 14:28-30); dan garam yang tawar (Luk. 14:34-35). ${ }^{19}$

Dengan demikian, pernyataan ini melukiskan bahwa iman yang sejati kepada Kristus Yesus menyebabkan mempelai perempuan atau gereja memiliki kekuatan, keteguhan, dan kesabaran bahkan bertahan dalam penderitaan sampai mempelai lakilaki yaitu Yesus Kristus datang kembali untuk menjemput mempelai perempuan tersebut.

\section{Matius 25:8}

Kata, "minyak," dalam bahasa Yunani disebut elaiou. Kata 'elaiou' dalam bentuk kata benda genetive singular neutor dan dalam bahasa Inggris disebut sebagai olive or oil oil.20 Oleh karena ayat ini menggunakan kasus genetive, maka gadis-gadis yang memiliki minyak adalah gadis-gadis bijaksana. Sedangkan gadis-gadis yang tidak mempunyai minyak dan pelita/obornya hampir padam adalah gadis-gadis bodoh, seperti Donald Guthrie dkk menyatakan:

Obor itu menjadi padam (ay. 8) bukan karena minyaknya sudah habis terbakar, tetapi karena obor itu memang tidak pernah berisi minyak dan gadis-gadis itu tidak dapat membuat obor mereka tetap menyala. Mengantuklah mereka semua lalu tertidur (ay. 5). Perbedaannya adalah ada yang menyiapkan pelitanya pada waktunya dan ada yang tidak menyiapkan pelitanya dan mencoba untuk bergantung pada orang lain waktu keadaan genting tiba. Siap sedia secara rohani bukanlah hal yang dapat dibagi-bagikan kepada orang lain apabila dalam keadaan genting, dan dalam hal ini, gadis-gadis yang bijaksana itu bukanlah mementingkan diri sendiri, tetapi bersikap realistis waktu mereka menolak untuk membagi minyaknya. Gadis-gadis bodoh tidak diizinkan masuk ke perjamuan sebab mempelai laki-laki tidak mengenal mereka secara pribadi (bdk. Mat. 7:21-23)

Dengan demikian, kelima gadis bijaksana yang memiliki minyak tidak menghendaki untuk membagikannya karena memang minyak tersebut tidak bisa dibagikan. Ungkapan minyak dalam konteks ini seperti yang telah dijelaskan di dalam ayat 3 dan 4 tersebut di atas, maka minyak menunjukkan iman yang sejati kepada Kristus Yesus. Dalam keadaan yang genting iman dan rohani kepada-Nya tetap menjadi kepemilikan orang itu, tidak bisa dibagikan separuh kepada orang lain. Karena itu, sebelum datang keadaan yang genting setiap orang perlu saling melayani dan saling membangun di dalam iman kepada Kristus Yesus.

${ }^{19}$ Tim Penyusun, Alkitab Penuntun Hidup Berkelimpahan (Jakarta: LAI \& Gandum Mas, 2010), hal.

${ }^{20}$ Scripture4all Foundation - www.scripture4all.org, 2010 
Karena itu, setiap orang yang telah percaya kepada Kristus perlu memiliki keteguhan imannya yang sungguh-sungguh kepada-Nya supaya tetap bertahan sampai kedatangan Kristus sebagai mempelai laki-laki bagi mempelai perempuan.

\section{Markus 6:13}

Kata "minyak," dalam bahasa Yunani disebut elaiO. Kata 'elaiO,' dipakai bentuk kata benda dative singular neutor dan dalam bahasa Inggris disebut to olive atau oil to oil. ${ }^{21}$ Kata minyak dalam konteks ini menggunakan kasus dative, maka fungsi minyak sebagai alat atau instrument. ${ }^{22}$ Minyak dalam konteks ini adalah minyak zaitun, maka difungsikan untuk mengoles bagian tubuh orang yang sakit supaya mereka beroleh kesembuhan.

Alkitab Penuntun Hidup Berkelimpahan menyatakan bahwa, "penyembuhan dengan jalan mengoleskan minyak hanya disebutkan di sini dan di Yakobus 5:14. Minyak mungkin dipakai sebagai lambang dari kehadiran dan kuasa Roh Kudus dan sebagai sarana untuk membangkitkan iman. ${ }^{23}$ Hal senada dikemukakan oleh Donald Guthrie dkk., menyatakan bahwa mengoles dengan minyak hanya disebutkan di sini, dalam Lukas 10:34 (suatu kejadian membantu si sakit) dan dalam Yakobus 5:14. Barangkali di sini harus dipandang sebagai tambahan bagi penyembuhan ajaib dan sebagai dorongan kepada iman. ${ }^{24}$

Pernyataan kedua pendapat di atas dapat dijelaskan bahwa penyembuhan seseorang dari penderitaan sakit penyakit yang dialaminya melalui doa dan penggunaan minyak zaitun untuk dioles atau diminum minyak zaitunnya, maka dapat membangkitkan iman orang itu kepada Kristus Yesus. Karena Kristus Yesus memakai sarana atau alat untuk penyakit orang disembuhkan.

Dengan demikian, orang-orang yang telah beroleh kesembuhan seharusnya memiliki kepercayaan kepada-Nya dan bagi orang percaya yang pernah menderita dan beroleh kesembuhan mesti percaya dan beriman sungguh-sungguh kepada Kristus Yesus.

\section{Lukas 7:46}

Kata, "Minyak," dalam bahasa Yunani disebut elaiO. Kata 'elaiO,' berbentuk kata benda dative singular neutor dan dalam bahasa Inggris disebut to olive atau oil to oil. ${ }^{25}$ Kata minyak dalam konteks ini menggunakan kasus dative, maka fungsi minyak sebagai alat atau instrument. ${ }^{26}$

Oleh karena kata 'minyak' dalam konteks ini menggunakan kasus dative singular neutor, maka sebenarnya salah satu fungsi minyak adalah mengurapi seseorang yang akan menjabat sebuah jabatan khusus, tetapi selama itu belum pernah para murid melakukannya kepada Kristus Yesus. Perempuan berdosa melakukannya sebagai tanda bahwa dia berdosa, sehingga mengharapkan kasih-Nya untuk pengampunan segala dosanya. Sasaran perempuan berdosa meminyaki Yesus dengan minyak wangi pada kaki-Nya, sebagai suatu kerendahan hatinya amat dalam kepada-Nya karena banyak dosanya.

${ }^{21}$ Scripture4all Foundation - www.scripture4all.org, 2010

22 Pdt. Dr. Paskalinus Busthan, M. Th., Bahan Ajar Program Doktor: Eksegesis Perjanjian Baru (Pontianak: STT Pontianak, 2016), 56

${ }^{23}$ Alkitab Penuntun Hidup Berkelimpahan, op.cit., 1590-1591

24 Donald Duthrie dkk., op.cit., 146

25 Scripture4all Foundation - www.scripture4all.org, 2010

26 Pdt. Dr. Paskalinus Busthan, M. Th., Bahan Ajar Program Doktor: Eksegesis Perjanjian Baru, op.cit., 56 
Dengan demikian, minyak dalam konteks ini bukanlah minyak zaitun, tetapi minyak wangi, yang mahal harganya, sebagaimana Donald Guthrie dkk., mengutarakan bahwa minyak zaitun adalah jauh lebih murah daripada minyak wangi. ${ }^{27} \mathrm{Hal}$ ini berarti bahwa minyak yang dipakai oleh perempuan berdosa saat meminyaki kaki-Nya dengan minyak wangi yang mahal harganya.

Frasa, "Engkau tidak meminyaki kepala-Ku dengan minyak," dalam tradisi Yahudi bila seseorang diberikan jabatan untuk dijalankan, misalnya raja, nabi, dan imam perlu diurapi dengan minyak sebagai suatu simbol bahwa orang tersebut telah diurapi oleh Allah karena itu telah layak untuk menjalankan tugasnya tanpa bimbang dan ragu. Sebagaimana Daud diurapi oleh Allah menjadi raja atas bangsa Israel yang kedua dengan simbol minyak (bdk. Mzm. 23:5). Alkitab Penuntun Hidup Berkelimpahan menarasikan bahwa meminyaki atau mengurapi kepala dengan minyak mengacu kepada perkenan dan berkat khusus dari Allah melalui urapan Roh Kudus-Nya atas tubuh, pikiran, dan roh, ${ }^{28}$ sehingga melaksanakan tugas pelayanannya dengan penuh kuasa dan berwibawa.

\section{Lukas 10:34}

Kata, "Minyak," dalam bahasa Yunani disebut elaion. Kata 'elaion,' dalam bentuk kata benda accusative singular neutor dan dalam bahasa Inggris disebut sebagai olive atau oil-oil. ${ }^{29}$ Kata minyak dalam konteks ini menggunakan kasus accusative, maka fungsi minyak sebagai obyek. ${ }^{30}$ Minyak dalam konteks ini adalah minyak zaitun, ${ }^{31}$ maka difungsikan untuk menyirami(nya) (TB-LAI, BIS); menuang(kan) (TL-LAI, Gideons, NIV); dan menyiramkan (Interlinear).

Dari beberapa terjemahan di atas menunjukkan bahwa orang Samaria yang menemui seseorang yang dicelakai oleh para penyamun di jalan jurusan Yerusalem ke Yerikho (bdk. 10:30). ${ }^{32}$ Orang Samaria membebat/membalut luka-lukanya kemudian menyiramkan dengan minyak zaitun dan air anggur (TL-LAI) kemudian dibawa ke rumah penginapan dan merawat dia.

Cara pertolongan yang diperbuat oleh orang Samaria ini adalah sebuah ungkapan kasihnya yang tulus ikhlas kepada orang yang dicelakai oleh para penyamun. Kasih ini adalah kasih yang diajarkan oleh Kristus Yesus kepada gereja masa itu dan terusmenerus berlaku di masa sekarang yakni kasihilah sesama manusia seperti dirimu sendiri (Mat. 22:39; bdk. Luk. 10:27).

\section{Lukas 16:6}

Kata, "Minyak," dalam bahasa Yunani disebut elaio. Kata 'elaio,” digunakan kata benda genetive singular neutor dan dalam bahasa Inggris disebut of olive atau oil of oil. ${ }^{33}$ Kata minyak dalam konteks ini adalah minyak zaitun ${ }^{34}$ dan menggunakan kasus genetive, maka fungsi minyak dalam konteks ini menyatakan sebagai obyek yang

27 Donald Guthrie, dkk., op.cit., 210-211

28 Tim Penyusun, Alkitab Penuntun Hidup Berkelimpahan, op.cit., 838

${ }^{29}$ Scripture4all Foundation - www.scripture4all.org, 2010

30 Pdt. Dr. Paskalinus Busthan, M. Th., Bahan Ajar Program Doktor: Eksegesis Perjanjian Baru,

31 Pdt. Hasan Sutanto, PIBK Jilid I (Surabaya: Momentum, 2014), hal. 373

32 Jalan jurusan Yerusalem ke Yerikho adalah sebuah jalan yang curam, 27 km panjangnya, turun 1000 meter dari Yerusalem ke Yerikho, yang merupakan suatu daerah kediaman bagi imam-imam (bdk. Luk. 1:23). Kisah itu merupakan kejadian nyata. Bandingkan Donald Guthrie dkk, op.cit., 219

${ }^{33}$ Scripture4all Foundation - www.scripture4all.org, 2010

34 Pdt. Hasan Sutanto, PIBK Jilid I, op.cit., 411 
dimiliki. ${ }^{35}$ Obyek yang dimiliki oleh orang yang berhutang adalah seratus tempayan minyak dan dianjurkan oleh bendahara agar membuat surat hutang menjadi lima puluh tempayan.

Donald Guthrie dkk menyatakan bahwa ukuran untuk minyak adalah tempayan (Yun. batos). Sedangkan ukuran untuk gandum adalah pikul (Yun. koros sama dengan \pm 345 liter). Karena satu tempayan minyak lebih murah dari satu pikul gandum, maka pengurangan-pengurangan itu adalah kira-kira sama. ${ }^{36}$

Pernyataan tempayan di atas menunjukkan bahwa wadah yang biasa dipakai untuk mengisi air atau minyak, sehingga dipergunakan untuk kebutuhan rumah tangga atau kebutuhan pada acara-acara tertentu. Dalam konteks ini dinarasikan bahwa tempayan ini berukuran kecil hanya ukuran 10 liter minyak. Berarti seratus tempayan sama dengan 1000 liter dan dapat dikurangi menjadi lima puluh tempayan, maka sama dengan 500 liter. Jadi, hutang yang harus dibayar oleh orang yang berhutang adalah 50 tempayan atau 500 liter minyak zaitun.

Dengan demikian, minyak zaitun dalam konteks ini membicarakan tentang hutang yang harus dibayarkan atau dilunasi oleh orang yang berhutang kepada tuannya.

\section{Ibrani 1:9}

Kata, "Minyak," dalam bahasa Yunani disebut elaion. Kata, "elaion," digunakan bentuk kata benda accusative singular neutor dan dalam bahasa Inggris disebut olive atau oil with oil. ${ }^{37}$ Kata minyak dalam konteks ini menggunakan kasus accusative, maka fungsi minyak sebagai obyek. ${ }^{38}$ Minyak dalam konteks ini adalah minyak kesukaan yang dipakai pada waktu perayaan, ${ }^{39}$ tetapi difungsikan juga untuk mengurapi (TB-LAI; diurapi (TL-LAI); anointing or anointed/meminyaki (NIV, Gideons).

Pernyataan di dalam konteks ini menggambarkan bahwa Allah Bapa melalui kuasa-Nya telah mengurapi Kristus Yesus. Kristus Yesus mencintai keadilan dan membenci kefasikan, sebagaimana Alkitab Penuntun Hidup Berkelimpahan menjelaskan bahwa, "Dalam pengabdian Kristus terhadap keadilan (Yes. 11:5) dan kebencian-Nya terhadap kejahatan dalam kehidupan, pelayanan, dan kematian-Nya." 40 Pengurapan yang telah diterima oleh Kristus Yesus, sehingga setia melaksanakan perintah Bapa, seperti dijelaskan di dalam Alkitab Penuntun Hidup Berkelimpahan yakni:

1. Kesetiaan Kristus kepada Bapa selama Ia berada di bumi, sebagaimana ditunjukkan oleh kasih-Nya terhadap keadilan dan kebencian-Nya atas kejahatan merupakan alasan bagi Allah untuk mengurapi Anak-Nya.

2. Kasih kita terhadap keadilan dan kebencian terhadap kejahatan akan meningkat melalui dua cara: (a) melalui pertumbuhan dalam kasih dan belas kasihan yang amat terhadap mereka yang hidupnya dihancurkan oleh dosa; (b) dengan mengalami kemanunggalan yang makin erat dengan Allah dan Juruselamat kita yang mencintai keadilan dan membenci kefasikan (bdk. Mzm. 94:16; 97:10; Ams. 8:13; Am. 5:15; Rm. 12:9; 1 Yoh. 2:15; Why. 2:6).41

Pernyataan ini melukiskan bahwa Allah mengurapi Kristus agar menyatakan keadilan, kebenaran, dan mengajarkan kasih kepada umat manusia. Dan urapan yang sama dikaryakan oleh Kristus kepada gereja-Nya untuk memberitakan berita kebenaran op.cit., 55

35 Pdt. Dr. Paskalinus Busthan, M. Th., Bahan Ajar Program Doktor: Eksegesis Perjanjian Baru,

36 Donald Guthrie dkk., op.cit., 233

37 Scripture4all Foundation - www.scripture4all.org, 2010

38 Pdt. Dr. Paskalinus Busthan, M. Th., Bahan Ajar Program Doktor: Eksegesis Perjanjian Baru, op.cit., 54

39 Pdt. Hasan Sutanto, PIBK Jilid I, op.cit., 1154.

40 Tim Penyusun, Alkitab Penuntun Hidup Berkelimpahan, op.cit., 2054

41 Ibid 
yang sejati kepada umat manusia agar tetap berpegang teguh pada kebenaran-Nya. Bahkan umat yang berdosa dapat bertobat, percaya, dan menerima Yesus Kristus di dalam kehidupannya.

\section{Yakobus 5:14}

Kata, "Minyak," dalam konteks ini dari bahasa Yunani disebut elaiO. Kata 'elaiO,' berbentuk kata benda dative singular neutor dan dalam bahasa Inggris disebut to olive oil.42 Kata minyak dalam konteks ini merujuk pada minyak zaitun yang difungsikan untuk menyembuhkan berbagai jenis ${ }^{43}$ penyakit dalam. ${ }^{44}$

Namun waktu mempergunakan minyak zaitun untuk mengoles (TB-LAI, BIS), mengurapi (TL-LAI), meminyaki/anoint (Interlinear, NIV), orang sakit sebenarnya diawali dengan doa. Ungkapan penyakit di dalam Yakobus 5:14-15 menyatakan bahwa penyakit secara jasmani yang dialami oleh manusia. Alkitab Penuntun Hidup Berkelimpahan menyatakan:

Yakobus berbicara tentang penyakit jasmaniah. Kita boleh menangani penyakit dengan minta doa dari penatua atau pemimpin gereja karena (1) tugas para gembala atau pemimpin gereja adalah mendoakan orang sakit dan mengoles mereka dengan minyak. Perlu diketahui tanggung jawab para penatua ialah menaikkan doa iman. Itu bukan tanggung jawab orang sakit. Perjanjian baru menempatkan beben utama untuk memperoleh kesembuhan pada gereja dan pemimpinnya; (2) minyak rupanya melambangkan kuasa Roh Kudus yang menyembuhkan; minyak itu dipakai untuk membantu iman (bdk. Mrk. 6:13); (3) Yakobus menekankan bahwa yang terpenting adalah doa. Doa yang efektif harus dinaikkan di dalam iman jikalau orang sakit akan disembuhkan. Tuhan akan memberikan iman sesuai dengan kehendak-Nya. ${ }^{45}$

Pernyataan di atas dapat dijelaskan bahwa penyakit jasmaniah yang dialami oleh setiap orang dapat disembuhkan melalui doa secara iman kepada Kristus Yesus dan pada bagian tubuh yang dirasa sakit bisa dioleskan dengan minyak zaitun. Minyak zaitun yang dipakai untuk mengoles/meminyaki orang sakit, maka orang itu akan sembuh, baik penyakit bagian dalam maupun bagian luar.

\section{Wahyu 6:6}

Kata, Minyak," dari bahasa Yunani disebut elaion. Kata 'elaion,' dalam bentuk kata benda accusative singular neutor dan dalam bahasa Inggris disebut sebagai olive atau oil. 46

Kata minyak dalam konteks ini disebut sebagai kebun zaitun ${ }^{47}$ dan menggunakan kasus accusative, maka fungsi minyak dalam konteks ini dipergunakan untuk pelengkap penderita. ${ }^{48}$ Karena sebagai pelengkap penderita, maka minyak dan anggur dalam konteks ini merujuk kepada pohon zaitun dan pokok anggur, yang tidak mengalami

\footnotetext{
${ }^{42}$ Scripture4all Foundation - www.scripture4all.org, 2010

43 Frasa yang bercetak miring dari penulis

44 Pdt. Dr. Paskalinus Busthan, M. Th., Bahan Ajar Syemenologi, op.cit., 16

45 Tim Penyusun, Alkitab Penuntun Hidup Berkelimpahan, op.cit., 2092-2093

46 Scripture4all Foundation - www.scripture4all.org, 2010

47 Pdt. Hasan Sutanto, D. Th., op.cit., 1312

48 Pdt. Dr. Paskalinus Busthan, M. Th., Bahan Ajar Program Doktor: Eksegesis Perjanjian Baru,
} op.cit., 54 
kerusakan oleh musim kering sebanyak tumbuh-tumbuhan berbiji. Walaupun kelaparan telah terjadi sepanjang zaman gereja (Mat. 24:7), bagian ini berkaitan dengan suatu kelaparan khusus selama masa kesengsaraan. ${ }^{49}$

Pernyataan ini menggambarkan bahwa pohon zaitun sebagai penghasil minyak zaitun mampu bertahan di musim kering/kemarau demikian pula pohon anggur. Pelarangan untuk merusakkan kebun pohon zaitun dan kebun pohon anggur mengandaikan cukupnya perbekalan dari bahan-bahan yang kurang dibutuhkan. Donald Guthrie dkk menyatakan:

Beberapa tahun sebelum kitab Wahyu ditulis (92 M), kekurangan gandum yang sangat gawat, dibarengi melimpahnya anggur di kerajaan Romawi menyebabkan kaisar Domitian memerintahkan pembatasan menanam anggur dan meningkatkan menanam gandum; perintah itu menyebabkan kehebohan sedemikian rupa sehingga harus dibatalkan..$^{50}$

Pernyataan senada dikemukakan oleh Simon J. Kistemaker bahwa beberapa penafsir merujuk dekrit Domitianus pada tahun $92 \mathrm{M}$, yang melarang kebun anggur baru ditanam di Italia dan separuh kebun anggur di provinsi-provinsi Romawi harus dimusnahkan. Para penanam anggur di Asia Kecil sangat kecewa oleh dekrit ini sehingga perintah itu dicabut sebelum sempat diterapkan. ${ }^{51}$ Pernyataan ini merupakan pernyataan sejarah tetapi bisa dirujuk pada penulisan kitab, sebagaimana lebih lanjut, Simon J. Kistemaker menyatakan, "Catatan sejarah ini bisa menolong untuk memahami masa Yohanes saat menulis Kitab Wahyu, tetapi ada dua keberatan: dekrit itu tidak pernah diberlakukan dan tidak mencatat tentang minyak. ${ }^{52}$

Walaupun dalam sejarah tidak mencatat tentang minyak, tetapi dalam konteks ini Yohanes telah diilhamkan atau dinubuatkan oleh-Nya tentang minyak untuk dituliskannya. Simon J. Kistemaker menyatakan bahwa, "Menurut beberapa teolog, orang kaya bisa membayar minyak dan anggur merupakan bahan pokok yang umum pada masa Yohanes: minyak dipakai untuk memasak dan anggur adalah minuman sehari-hari. Mengapa orang kaya merusakkan bahan-bahan pokok ini? Jadi, larangan ini lebih baik dikaitkan dengan alam. Dengan kata lain, perintah ini menjadi "batasan bagi malapetaka yang Tuhan tetapkan."53

Pernyataan ini dapat dijelaskan bahwa yang ingin merusakkan kebun pohon zaitun dan kebun pohon anggur adalah bukan alam tetapi para antikristus yang kaya raya. Para antikristus menghendaki agar orang-orang Kristen yang notabene orang miskin sebagai pengusaha kebun minyak zaitun dan kebun anggur harus dimusnahkan. Kalau kebun pohon zaitun dan kebun pohon anggur dimusnahkan berarti orang Kristen tidak akan bertahan hidup dan kalaupun mereka hidup hanya menjadi budak bagi orang kaya.

Dengan demikian, minyak dalam konteks ini menarasikan mengenai pohon kebun zaitun yang dapat menghasilkan minyak zaitun dan dapat dijual dengan harga yang tinggi untuk menunjang kehidupan keluarga serta dipergunakan untuk memasak.

\section{Wahyu 18:13}

\footnotetext{
49 Tim Penyusun, Alkitab Penuntun Hidup Berkelimpahan, op.cit., 2162

50 Donald Guthrie dkk., op.cit., hal. 910

51 Simon J. Kistemaker, Tafsiran Kitab Wahyu (Surabaya: Momentum, 2009), 246

52 Ibid

53 Ibid
} 
Kata, Minyak," dalam bahasa Yunani disebut elaion. Kata 'elaion,' dalam bentuk kata benda accusative singular neutor dan dalam bahasa Inggris disebut sebagai olive or oil oil. 54

Kata minyak dalam konteks ini disebut sebagai minyak zaitun ${ }^{55}$ dan menggunakan kasus accusative, maka fungsi minyak dalam konteks ini dipergunakan sebagai objek. ${ }^{56}$ Karena sebagai objek, maka minyak dalam konteks ini merujuk kepada minyak zaitun.

Minyak zaitun merupakan kebutuhan sehari-hari yang pada umumnya ada di setiap rumah tangga. Minyak zaitun dapat dihasilkan dari buah pohon zaitun. Karena itu pohon zaitun tumbuh di mana-mana dan menghasilkan minyak untuk masak dan mengusir kegelapan dalam konteks masa lampau. ${ }^{57}$ Dengan demikian, minyak zaitun dalam konteks ini sebagai objek untuk masak dan mengusir setan atau kegelapan yang menguasai setiap orang.

B. Kata Yunani "aleipho" yang artinya mengurapi dengan minyak; mengoles dengan minyak (Mat. 6:17; Mrk. 6:13; 16:1; Luk. 7:38, 46; Yoh. 11:2; 12:3; Yak. 5:14).

\section{Matius 6:17}

Kata, Minyak," dari bahasa Yunani disebut aleipsai. Kata 'aleipsai,' berbentuk kata kerja (m) aorist middle orang ke-2 single. ${ }^{58}$ Kata 'aleipsai,' berasal dari ó $\lambda \varepsilon \varepsilon i \varphi \omega$, yang artinya adalah meminyaki, mengurapi, ${ }^{59}$ dan dari kata Inggris $r u b$ atau $r u b$ you ${ }^{60}$ yang artinya gosokan atau menggosokmu. ${ }^{61}$

Kata minyak dalam konteks ini menggunakan kasus aorist. ${ }^{62}$ Berdasarkan tense yang dipergunakan, maka kata tersebut dapat dijelaskan bahwa pada masa lalu, engkau pernah mengurapi kepala dan cuci muka atau basuhlah mukamu (TL-LAI) bila berpuasa. Kata "engkau" dalam konteks ini merujuk kepada para murid-Nya.

\section{Markus 6:13}

Kata, "Minyak," dalam bahasa Yunani disebut Eleiphon. Kata 'Eleiphon,' bentuk kata kerja indicative imperative active orang ketiga jamak dan dalam bahasa Inggris disebut they rubbed.63

Kata minyak dalam konteks ini menggunakan kasus imperative. ${ }^{64}$ Dalam konteks ini fungsi minyak dipergunakan (1) untuk mengoles banyak orang sakit; (2)

${ }^{54}$ Scripture4all Foundation - www.scripture4all.org, 2010

55 Pdt. Hasan Sutanto, D. Th., op.cit., 1358

${ }^{56}$ Pdt. Dr. Paskalinus Busthan, M. Th., Bahan Ajar Program Doktor: Eksegesis Perjanjian Baru, op.cit., 54

57 Simon J. Kistemaker, op.cit., 537

${ }^{58}$ Scripture4all Foundation - www.scripture4all.org, 2010

${ }^{59}$ Barclay M. Newman Jr., Kamus Yunani - Indonesia (Jakarta: BPK Gunung Mulia, 2004), 6

${ }^{60}$ Scripture4all Foundation - www.scripture4all.org, 2010

${ }^{61}$ John M. Echols \& Hassan Shadily, op.cit., hal. 493

${ }^{62}$ Aorist artinya pekerjaan yang pernah dilakukan pada masa lalu, satu kali dan tidak dilakukan terus-menerus. Atau untuk menyatakan bahwa suatu pekerjaan pernah terjadi atau dilakukan. Tidak menyatakan terus-menerus dilakukan atau berulang kali dilakukan. Atau menyatakan pekerjaan yang hanya dilakukan sesaat, sedetik.

${ }^{63}$ Scripture4all Foundation - www.scripture4all.org, 2010

${ }^{64}$ Imperative mood adalah bentuk kata kerja yang menyatakan perintah (bentuk kata kerja perintah). Bandingkan Pdt. Dr. Paskalinus Busthan, M. Th., Bahan Ajar Program Doktor: Eksegesis Perjanjian Baru, op.cit., 43 
menyembuhkan mereka dengan minyak. Jadi, dalam pelayanan para murid masa itu perlu mereka mengusir banyak setan dan menyembuhkan orang-orang dengan minyak zaitun sebagai simbolisme dari kehadiran Roh Kudus untuk kesembuhan dinyatakan dalam Kristus Yesus.

Alkitab Penuntun Hidup Berkelimpahan menarasikan bahwa penyembuhan dengan jalan mengoles minyak hanya disebutkan di ayat ini dan di Yakobus 5:14. Minyak dipakai sebagai lambang dari kehadiran dan kuasa Roh Kdus dan sebagai sarana untuk membangkitkan iman. ${ }^{65}$

\section{Markus 16:1}

Kata, "meminyaki," dalam bahasa Yunani disebut aleipsOsin. Kata, aleipsOsin, bentuk kata kerja sandang aorist active orang ketiga jamak dan dalam bahasa Inggris disebut they should be rubbing. ${ }^{66}$ Kata meminyaki dalam konteks ini menggunakan kasus aorist. Berdasarkan tense yang dipergunakan, maka kata tersebut dapat dijelaskan bahwa pada masa lalu, mereka pernah pergi meminyaki Yesus. Kata meminyaki menggunakan orang ketiga jamak, maka berarti mereka menurut konteks ini. Jadi, kata "mereka" dalam konteks ini merujuk kepada Maria Magdalena, Maria ibu Yakobus, dan Salome.

Ungkapan aleipsOsin bila diterjemahkan ke dalam bahasa Inggris disebut they should be rubbing. Ungkapan ini dapat dipahami bahwa mereka harus meminyaki/mengurapi. Ungkapan aleipsOsin menunjukkan tiga orang perempuan sebagaimana yang dikemukakan oleh Matthew Henry bahwa kunjungan penuh kasih dari tiga orang perempuan baik-baik yang merupakan pengikut Kristus ke kubur-Nya. ${ }^{67}$ Ketiga pengikut Kristus dalam pernyataan ini adalah Maria Magdalena, Maria ibu Yakobus, dan Salome. Mereka adalah pengikut Kristus yang sejati tanpa ada perasaan keragu-raguan di dalam hidup mereka.

Saat Yesus wafat dan dikuburkan, kepedulian mereka terhadap-Nya sangat tinggi di mana keinginan mereka untuk berangkat ke kubur-Nya dengan membawa rempahrempah untuk meminyaki mayat-Nya, sebagaimana Matthew Henry menjelaskan bahwa mereka telah membeli (Yun. Egorasan) ${ }^{68}$ rempah-rempah dan datang bukan saja untuk membasahi mayat-Nya dengan air mata mereka (sebab tidak ada lagi yang dapat menghibur kesedihan mereka selain ini), melainkan juga untuk meminyaki tubuh-Nya dengan rempah-rempah (Mrk. 16:1). ${ }^{69}$

Selain, ketiga perempuan tersebut di atas tetapi Nikodemus juga melakukan terhadap Yesus Kristus seperti yang dapat dijelaskan oleh Matthew Henry bahwa, "Nikodemus telah membeli banyak sekali rempah-rempah dan campuran minyak mur dengan minyak gaharu, untuk mengeringkan luka-luka dan menghentikan pendarahan (Yoh. 19:39).70 Lebih lanjut, Matthew Henry menyatakan bahwa namun, perempuanperempuan yang baik ini tidak menganggap semua ini sudah cukup. Mereka membeli rempah-rempah, mungkin dan jenis lain, dan beberapa minyak wangi untuk meminyakiNya. ${ }^{71}$ Pada saat mereka membawa rempah-rempah untuk meminyaki Yesus, tetapi Dia telah bangkit pagi-pagi pada hari pertama minggu itu dari antara orang mati (bdk. Mrk. $16: 6,9)$.

65 Tim Penyusun, Alkitab Penuntun Hidup Berkelimpahan, op.cit., 1591

66 Scripture4all Foundation - www.scripture4all.org, 2010

67 Matthew Henry, Tafsiran Matthew Henry Injil Markus (Surabaya: Momentum, 2015), 384

${ }^{68}$ Egorasan dari kata ó $\gamma o \rho \alpha ́ \zeta \omega$, yang artinya adalah membeli, menebus. Bandingkan Barclay Newman Jr., Kamus Yunani Indonesia, Jakarta: BPK Gunung Mulia, 2004, 2

69 Matthew Henry, op.cit., 384

70 Ibid. 384-385

71 Ibid. 385 


\section{Lukas 7:38}

Kata, "Minyak," dari kata Yunani disebut Eleiphen. Kata 'Eleiphen,' berbentuk kata kerja indicative imperative active orang ke-3 singular, dan dalam bahasa Inggris disebut rubbed, yang artinya adalah menggosok, menggosok-gosokan ${ }^{72}$ atau rubbed them, yang artinya menggosok mereka.

Kata minyak dalam konteks ini menggunakan kasus imperative. ${ }^{73}$ Oleh karena kata minyak menggunakan kasus imperative active orang ketiga singular, maka yang bertindak meminyaki kaki Yesus dengan minyak wangi adalah ia. Kata 'ia,' ditujukan kepada perempuan berdosa. Menurut konteks di ayat ini dapat dinarasikan bahwa perempuan berdosa melakukan beberapa tindakan konkret, yakni: (1) perempuan berdosa menangisi akan perbuatan dosanya di belakang Yesus dekat kaki-Nya; (2) perempuan berosa membasuh kaki Yesus dengan air matanya; (3) perempuan berdosa menyeka kaki Yesus dengan rambutnya; (4) perempuan berdosa mencium kaki Yesus; (5) perempuan berdosa meminyaki kaki Yesus dengan minyak wanginya.

Dari beberapa tindakan konkret yang diperbuat oleh perempuan berdosa dan tindakan kelima merupakan sebuah tindakan pengorbanan berupa kekayaan yang dimilikinya. Mengawali tindakan pengorbanan yang ditunjukkannya kepada Yesus Kristus, maka dia mengungkapkan perasaan kesedihan akan perbuatan dosanya, sebagaimana Alkitab Penuntun Hidup Berkelimpahan menjelaskan, "Karena kasihnya kepada Kristus Yesus, perempuan ini membasahi kaki Yesus dengan air matanya. Menangis dapat merupakan ungkapan kesedihan dan dukacita atau ungkapan kasih yang berterima kasih kepada Yesus. ${ }^{74}$ Ungkapan tangisan yang ditunjukkan oleh perempuan berdosa disertai dengan tindakan pengorbanan yang dilakukannya meyakini bahwa Yesus Kristus pasti mengampuni dosanya dan menerima dirinya sebagai pengikut-Nya.

\section{Lukas 7:46}

Kata, "minyak" dari kata Yunani adalah Eleipsas. Kata Eleipsas, berbentuk kata kerja indicative aorist active orang ke-2 singular. Kata Eleipsas dalam bahasa Inggris disebut you rub. ${ }^{75}$ Kata minyak dalam konteks ini menggunakan kasus aorist active orang ke-2 tunggal, yang artinya bahwa pada waktu lalu pernah mengurapi, tetapi ternyata tidak dilakukan oleh engkau. Kata 'engkau' merujuk pada para murid Yesus Kristus. Jadi, pada waktu dulu para murid tidak pernah meminyaki kepala Yesus dengan minyak zaitun.

Kata Eleipsen, berbentuk kata kerja aorist active orang ke-2 singular dan dalam bahasa Inggris disebut rubs. ${ }^{76}$ Kata minyak dalam konteks ini menggunakan kasus aorist active orang ke-2 tunggal yang artinya bahwa pada masa lalu pernah dilakukan mengurapi. Dan yang mengurapi adalah dia. Kata 'dia' merujuk pada perempuan berdosa. Perempuan berdosa mengurapi/meminyaki kaki Yesus dengan minyak wangi.

\section{Yohanes 11:2}

72 John M. Echols \& Hassan Shadily, Kamus Inggris Indonesia (Jakarta: Penerbit PT Gramedia Jakarta, 2005), 493

73 Imperative mood adalah bentuk kata kerja yang menyatakan perintah (bentuk kata kerja perintah). Bandingkan Pdt. Dr. Paskalinus Busthan, M. Th., Bahan Ajar Program Doktor: Eksegesis Perjanjian Baru, op.cit., 43

${ }^{74}$ Alkitab Penuntun Hidup Berkelimahan, op.cit., 1643

75 Scripture4all Foundation - www.scripture4all.org, 2010

76 Ibid 
Frasa, "pernah meminyaki" dari kata Yunani adalah aleipsasa. Kata aleipsasa, berbentuk kata kerja participle aorist active nominative singular feminine. ${ }^{77}$ Kata aleipsasa dalam bahasa Inggris disebut one rubbing.

Kata minyak dalam konteks ini menggunakan kasus aorist active orang ke-1 tunggal, yang artinya bahwa pada waktu lampau pernah meminyaki kaki Tuhan dengan minyak mur dan menyekanya dengan rambutnya. Konteks ini menggunakan kasus nominative singular feminine, maka subyek yang bertindak saat meminyaki kaki Tuhan Yesus adalah Maria. Nama 'Maria' merujuk pada saudara Lazarus yang tinggal di Betania. Hal ini selaras dengan Terjemahan Lama LAI mengungkapkan ayat ini bahwa, "Maka Maryam itulah yang mengurapi Yesus dengan minyak bau-bauan, dan yang menyapu kakinya dengan rambutnya, yang empunya saudara laki-laki bernama Lazarus, yang sakit itu." Jadi, pada waktu dulu Maria pernah meminyaki (TB-LAI), mengurapi (TL-LAI) kaki Yesus dengan minyak mur (TB-LAI), minyak bau-bauan (TL-LAI) dan menyekanya (TB-LAI) menyapu (TL-LAI) dengan rambutnya.

Minyak yang dipakai Maria untuk meminyaki kaki Yesus adalah minyak mur, yang bau harumnya. Kamus Alkitab TB-LAI mengisahkan bahwa minyak mur adalah damar yang harum baunya, yang dipakai untuk persembahan (Mat. 2:11), sebagai obat (Mrk. 15:23) dan dalam mempersiapkan jenazah orang untuk penguburan (Yoh. 19:39). ${ }^{78}$

Dengan demikian, minyak mur merupakan salah satu minyak terbaik yang dipergunakan oleh orang-orang majus dari Timur untuk mempersembahkan kepada Yesus. Minyak mur dipakai juga untuk obat untuk menyembuhkan beberapa penyakit dan sebagai sarana untuk mengharumkan jenazah supaya tetap awet dan harum baunya.

\section{Yohanes 12:3}

Kata, "meminyaki," dari kata Yunani adalah Eleipsen. Kata Eleipsen, berbentuk kata kerja indicative aorist active orang ke-3 singular. ${ }^{79}$ Dan dalam bahasa Inggris disebut rubs.

Kata meminyaki dalam konteks ini menggunakan kasus aorist orang ke-3 tunggal yang artinya bahwa pada waktu dulu pernah dia meminyaki. Kata dia dalam konteks ini mengarah kepada Maria. Menurut konteks ini Maria melakukan beberapa tindakan nyata yakni: (1) Maria meminyaki kaki Yesus dengan setengah kati ${ }^{80}$ minyak narwastu ${ }^{81}$

\footnotetext{
77 Ibid

${ }^{78}$ Kamus Alkitab (Jakarta: Penerbit LAI, 2011), 375

79 Ibid
}

${ }^{80}$ Ungkapan setengah kati diterjemahkan dalam bahasa Yunani adalah litran. Satu litran sama dengan 327,45 gram. Menurut Donald Guthrie dkk., bahwa Maria mengambil setengah kati minyak narwastu murni yang mahal harganya (kati $=3,75 \mathrm{~kg}$ ). Arti perkataan nurni pada dasarnya adalah meyakinkan atau dapat dipercaya tetapi gagasan tentang kesejatian pasti lebih tepat. Minyak narwastu rupanya adalah parfum cair. Lalu meminyaki kaki Yesus. Cara basa-basi ialah mengurapi kepala, bukan kaki, selaku tanda penghormatan. Dalam cerita pengurapan yang sejajar dengan ini dalam Lukas 7:38 adalah kaki juga yang diurapi. Terdapat banyak persamaan antara cerita dalam Yohanes dengan cerita Lukas, tetapi tidaklah tepat untuk menyamakan kedua perempuan yang bersangkutan. Perempuan dalam cerita Lukas adalah perempuan berdosa yang digambarkan sebagai orang yang sangat menyesal, sedangkan perempuan di sini, secara mendalam mengabdi kepada Yesus dan bersesuaian sama sekali dengan gambaran tentang Maria dari Betania dalam Lukas. Dalam kedua peristiwa ini kaki Yesus diseka dengan rambut perempuan itu. Adalah bertentangan dengan adat istiadat Yahudi bagi seorang nyonya rumah tampil di depan kaki-kaki dengan rambut yang tidak terikat, tetapi dalam hal Maria, kasih adalah lebih kuat daripada adat. Catatan Yohanes mengenai bau minyak semerbak di seluruh rumah itu adalah perincian yang hidup, yang tidak mudah dilupakan orang yang hadir pada waktu itu (hal. 309). 
murni yang mahal harganya; (2) Maria menyeka kaki-kaki Yesus dengan rambutrambutnya.

\section{Yakobus 5:14}

Kata, "minyak," dari kata Yunani adalah aleipsantes. Kata Eleipsen, berbentuk kata kerja participle aorist active nominative plural masculine. Dan dalam bahasa Inggris disebut rubbing.

Kata minyak dalam konteks ini menggunakan kasus aorist active nominative plural masculine yang artinya bahwa pada waktu dulu pernah para penatua jemaat mengoles orang sakit dengan minyak dalam nama Tuhan. Menurut konteks ini para penatua jemaat melakukan beberapa tindakan nyata untuk seseorang atau orang yang sakit yakni: (1) para penatua jemaat mendoakan mereka yang sakit; (2) para penatua jemaat mengolesnya dengan minyak dalam nama Tuhan Yesus Kristus untuk kesembuhan mereka yang mengalami penderitaan sakit.

Tindakan-tindakan di atas sangat baik untuk dipraktikkan supaya mereka yang menderita sakit dapat menerima pemulihan dari penyakit yang diderita. Bahkan minyak yang dipakai untuk mengoles pada bagian-bagian tubuh manusia yang sakit supaya cepat mendapatkan pemulihan dari campur tangan Tuhan Yesus Kristus.

\section{Kesimpulan}

Berdasarkan pemamaran dari riset di atas, maka dapat dikonklusikan bahwa pada prinsipnya semua minyak makan bila dipergunakan sesuai dengan takarannya akan bermanfaat bagi tubuh manusia. Kegunaan minyak selain di makan, tetapi juga baik untuk memijat organ tubuh yang sakit dan untuk kebutuhan lainnya.

Berbeda dengan minyak zaitun. Minyak zaitun dipergunakan untuk: (1) pengganti minyak makan untuk kebutuhan rumah tangga; (2) menyembuhkan berbagai jenis penyakit, baik penyakit dalam maupun penyakit kulit; (3) sebagai simbol untuk mengurapi seseorang yang akan menjalankan tugas dalam jabatan tertentu misalnya sebagai guru atau menjadi pelayan Kristus Yesus; (4) mengurut/memijat pada organorgan tubuh yang mengalami penderitaan kesakitan.

\section{Referensi}

, Kamus Alkitab (Jakarta: Penerbit LAI, 2011)

Athiroh, N. A. S., Scurrula atropurpurea increases nitric oxide and decreases malondialdehyde in hypertensive rats (....: Universa Medicana, 2012)

Busthan, Paskalinus, Bahan Ajar Program Doktor: Eksegesis Perjanjian Baru (Pontianak: STT Pontianak, 2016)

Busthan, Paskalinus, Bahan Ajar Syemenologi (Pontianak: STT Pontianak, 2017)

Corey, Gerald, Teori dan Praktek Konseling dan Psikoterapi, penerjemah E. Koeswara (Bandung: Penerbit PT. Refika Aditama 2008)

Dinas Kesehatan Propinsi Jawa Timur, Profil Kesehatan Provinsi Jawa Timur Tahun 2009 (Surabaya: Dinkes Propinsi Jatim, 2010)

81 Minyak narwastu adalah sejenis bau-bauan yang dibuat dari akar serai wangi (bdk. Kid. 1:12; 4:13-14; Mrk. 14:3; Yoh. 12:3). Bandingkan Terjemahan dari Lembaga Alkitab Indonesia, Jakarta: LAI, 2011. Ungkapan minyak wangi narwastu diterjemahkan ke dalam bahasa Yunani disebut $\mu$ úpou vó $\rho \delta o v$, yang artinya adalah minyak wangi narwastu (bdk. Yoh. 12:3). 
Guthrie, Donald, dkk., Tafsiran Alkitab Masa Kini 3 Matius - Wahyu (Jakarta: YKBK/OMF, 1999)

H. T. Prasetyorini HT \& D. Prawesti, Stress Pada Penyakit Terhadap Kejadian Komplikasi Hipertensi Pada Pasien Hipertensi (....: Jurnal STIKES, 2012)

Henry, Matthew, Tafsiran Matthew Henry Injil Markus (Surabaya: Momentum, 2015)

Ikawati, dkk., Kajian Keamanan Pemakaian Obat Antihipertensi di Poliklinik Usia Lanjut RS DR. Sardjito (Yogyakarta: Jurnal Farmasi Indonesia, 2008)

John M. Echols \& Hassan Shadily, Kamus Inggris Indonesia (Jakarta: Penerbit PT Gramedia Jakarta, 2005)

Kistemaker, Simon J., Tafsiran Kitab Wahyu (Surabaya: Momentum, 2009)

Newman, Barclay Jr., Kamus Yunani Indonesia, Jakarta: BPK Gunung Mulia, 2004)

Ridjab, D. A., Pengaruh Aktivitas Fisik terhadap Tekanan Darah (Jakarta: Majalah Kedokteran Atma Jaya, 2011)

Scripture4all Foundation - www.scripture4all.org, 2010

Supriadi, Deni, Pengaruh Persepsi Siswa Tentang Metode Mengajar Guru dan Pemanfaatan Sarana Belajar IPS Terpadu Siswa Kelas VII Semester Ganjil SMP 17 Serdang Tahun Pelajaran 2012/2013 (....: Unila, 2013)

Sutanto, Hasan, PIBK Jilid I (Surabaya: Momentum, 2014)

Syamsudin, A. R., Metode Penelitian Pendidikan Bahasa (Bandung: PT. Remaja Rosdakarya, 2011)

Tim Penyusun, Alkitab Penuntun Hidup Berkelimpahan (Jakarta: Penerbit Gandum Mas \& LAI, 2010)

Trubus, Herbal Indonesia Berkhasiat: Bukti Ilmiah dan Cara Racik (Bogor: Trubus Swadaya, 2010) 